\title{
Putting Pedagogy where Intention to Innovate Lies: Evaluating Compulsory Entrepreneurship Education
}

\begin{abstract}
The growing interest in entrepreneurship education has caused a debate about pedagogy can support intention to innovate. Drawing on the theory of planned behavior (TPB), we examine the links between experiential pedagogy and students' intention to innovate and entrepreneurial intent. Using structural equation modeling on a survey of 361 students of compulsory entrepreneurship education arrass public and private universities, we find that: (a) regardless university type out-of-_ experiences and engaged faculty generate positive behavioral control and attitude towards entrepreneurship; (b) out-of-class experiences significantly increases intentions to innovate; (c) behavioral control mediates the relationship between out-of-class experiences and changes in intention to innovate. (d) university type - public or private - has no direct significant effect on the students intention to innovate. The results contribute to theories of entrepreneurship education and intentions to innovate in higher education.
\end{abstract}

Keywords: Experiential Learning, Pedagogy, Entrepreneurship Education, Innovative Entrepreneurship, Higher Education Policy

AWARD: Consider for MED Best Paper in Management Education Award. 


\section{INTRODUCTION}

Entrepreneurship is an important generator of jobs and economic growth (Van Praag and Versloot, 2007; Birch, 1979). For this reason, most emerging economies across Africa with high levels of youth unemployment, have turned to policies on entrepreneurship education and training in Higher Education Institutions (HEI) to stimulate entrepreneurial activities. In Nigeria, for instance, the government introduced the policy of compulsory courses in entrepreneurship across all public and private universities (Dakung et al., 2017) to create self-employed graduates and other job opportunities (Thaddeus, 2012).

The logic behind entrepreneurship education is that it stimulates entrepreneurial intention, which enhances proactive behaviors toward entrepreneurial opportunities. Such behaviors potentially lead to the creation of new ventures and job creation (Greene et al., 2004), ultimately contributing to economic growth (Bosma et al., 2008; Van Praag and Versloot, 2007; Acs, 2006). However, evidence examining the effect of entrepreneurship education on entrepreneurial intention is equivocal with reports of both positive effects (e.g., Rauch and Hulsink, 2015; Martinez et al., 2010; Souitaris et al., 2007) and negative effects (von Graevenitz et al., 2010; Oosterbeek et al., 2010). In addition, the link between entrepreneurship education and entrepreneurial activity is not well established in the literature (Baumol, 2004).

Three main issues emerge from the large body of empirical research on entrepreneurship education outcomes. First, context matters when assessing the outcomes of entrepreneurship education (Arranz et al., 2017; Nabi et al., 2017; Nowiński et al., 2017). For instance, whether a course is elective or compulsory impacts on outcomes. Most studies that assessed elective courses in entrepreneurship reported positive impact on entrepreneurial self-efficacy (e.g., Gielnik et al., 2015), attitude and entrepreneurial intention (Rauch and Hulsink, 2015; Souitaris et al., 2007). In contrast, most studies that assess compulsory courses in entrepreneurship reported negative impact on entrepreneurial intention (e.g., von Graevenitz et al., 2010; Mentoor and Friedrich, 2007; Hytti et al., 2010). Another contextual factor that affects the outcome of entrepreneurship education is type of university - public vs private 
(Canever et al., 2017; Zhang et al., 2014; Perim, 2015). In their cross-sectional study, Pihie et al. (2013) find that entrepreneurial intentions of students from private universities are higher than their counterparts from public universities. It is important to explore these contextual factors in a single study to unpick their effects given the importance of context to the impact of entrepreneurship education on students' behavior.

Second, experiential pedagogy, teaching practices consistent with Kolb's (1984) experiential learning theory, plays a central role in determining the impact of entrepreneurship education (Nabi et al., 2017; Dakung et al., 2017; Pittaway and Cope, 2007). Following Kolbs's theory we define experiential pedagogy as those teaching practices within and outside the classroom that engage students in active learning by action and reflection. Examples of action learning include the use of venture creation, business plan competition, field trips, consultation with practicing entrepreneurs or computer and behavioral simulations, group work, relationship with faculty and other co-curricular activities (Mayhew et al., 2012). Scholars suggest that regardless of the context, experiential pedagogy is linked to innovative outcomes and cultivates innovative entrepreneurs (Neck and Greene, 2011; Mayhew et al., 2012; Baumol et al., 2009). Investigating this link is important to strengthen the theory of how innovative entrepreneurs - people who engage in creative processes that lead to new product process or service, can be trained.

Third, beyond contextual and pedagogical factors, novel impact indicators provide new insights and advance the conversation on the impact of entrepreneurship education (Nabi et al., 2017). We argue that one such novel impact indicator is intention to innovate - the motivation to exploit new entrepreneurial opportunities (Mayhew et al., 2012). Whereas entrepreneurial intention in general helps to predict entrepreneurial behavior, it is insufficient to predict innovative entrepreneurship because it does not distinguish the nature of entrepreneurship an individual plan to pursue. To the extent that intention is the best predictor of behavior, intention to innovate is a precursor to innovative entrepreneurship. Therefore, to extend the conversation on innovative entrepreneurship, it is essential to study intent to innovate as an additional impact indicator for assessing the impact of compulsory entrepreneurship education courses.

These three distinct yet related research issues form the rationale for our study. Our objective is to examine the effects of compulsory entrepreneurship education across public and 
private universities and unpick the role of experiential pedagogy on intent to innovate and entrepreneurial intent. Thus, we raise three research questions. 1) Does a compulsory course in entrepreneurship education affect students' intention to innovate? 2) Can experiential pedagogy influence intent to innovate? 3) Does the impact of compulsory courses in entrepreneurship vary across public and private universities?

The main strength of our work here is the adoption of an integrated theoretical framework and empirical strategy (see figure 1) that explores contextual factors, experiential pedagogy and mediators that explain changes in intent to innovate and entrepreneurial intent. These mediators are particularly useful because they elucidate the causal mechanisms that affect innovative entrepreneurship (Davidsson, 2007; Gielnik et al., 2015). By addressing these issues in a single study, our work provides new perspectives to contradictory evidence examining the effects of compulsory entrepreneurship courses, contributes to the entrepreneurship education theory, and equips educators as well as policymakers with information to cultivate innovative entrepreneurs.

Another strength of our work is the use of a novel research context to test existing entrepreneurship theories. Critics call for more management research in Africa to test (or redefine) existing theories on entrepreneurship education (George et al., 2016; Nkomo, 2015; Nowiński et al., 2017; Nabi et al., 2017). In response, we focus on Nigeria Higher Education and Institutions as an empirical context. When juxtaposed to a developed economy, the political and socioeconomic dynamics of an emerging economy such as Nigeria raise different challenges. First, the country faces multiple socio-cultural and political issues such as insecurity in the North-Eastern part of the country due to Boko Haram terrorist group, the security challenges in the South-Eastern part of the country caused by the recent agitation for the secession of the Biafra region from Nigeria (George et al., 2016). Second, economic challenges such as recent economic recession have led to more education budget cuts and high graduate unemployment. Approximately $33.1 \%$ of youths aged 15 to 24 , and $20.2 \%$ for those aged 25 to 34 are unemployed (NBS, 2017, p. 2). The recent sharp decline in crude oil prices - the most significant source of revenue, exacerbates this situation (WENR, 2017). Third, due to funding 
constraints created by budget cuts, there is a shortage of qualified academic staff and lecture halls are severely overcrowded especially in public universities. In one case, Obafemi Awolowo University saw its academic staff increased from 962 to 973 (1\%) between 1988 and 1998; but in the same period, student enrollment rose by 56\% (Hartnett, 2000). Fourth, historically, public universities have a lower staff to students ratio than private universities. For instance, a report in 2012, found that the University of Abuja and Lagos State University (both public universities), had lecturer to student ratios as high as 1:122 and 1:114 respectively (WENR, 2017). Finally, the government introduced the policy of compulsory courses in entrepreneurship for all students across public and private universities (Dakung et al., 2017). Together, these factors make the Nigeria HEI an interesting empirical context to evaluate the effect of compulsory entrepreneurship education across public and private universities.

\section{THEORY AND HYPOTHESIS}

\section{Entrepreneurial Intention and the Case for Intention to Innovate}

In our study, we make a distinction between general intention to pursue an entrepreneurial career - entrepreneurial intention, and a more specific intention to exploit new entrepreneurial opportunities -intention to innovate (Shane and Venkataraman, 2000). Entrepreneurial intention is the conviction by a person to set up a new business venture and consciously plan to do so at some point in the future (Thompson, 2009). Based on Lumpkin and Dess (1996) definition of innovativeness, we define intention to innovate as a conscious plan to engage in and support new ideas, novelty, experimentation, and creative process that may result in new product, service or process. To the extent that innovation may vary in its degree of "radicalness," intent to innovate may also vary along a continuum from low to high. Low intent to innovate refers to plan(s) to only improve existing goods and services by other entrepreneurs and appropriating some of their entrepreneurial profits. High intent to innovate, refers to plan(s) to discover and exploit new entrepreneurial opportunities and create new goods and services within a domain or a context. Regardless of degree, intent to innovate represents an individual's plan to deviate from the existing state of the art and venture into new ones. 
As Krueger eloquently remarks, "intentions are the single best predictor of any planned behavior" (Krueger et al., 2000, p. 412). Innovative entrepreneurship, like any planned behavior, is hard to observe and involves "unpredictable time lags" (Souitaris et al., 2007, p. 568). Moreover, from a research standpoint, it is not always practicable to wait some years to examine how many students eventually start a business and what type of businesses they start. Since intention is the best predictor of behavior, assessing intention as an outcome of entrepreneurship education is a pragmatic way to predict the likelihood of entrepreneurial action. Therefore, intention to innovate is arguably sufficient and appropriate to help predict innovative entrepreneurship.

We argue that both types of intentions share the same antecedents and remain predictors of behaviors. In line with this, we turn our attention to Ajzen's widely used Theory of Planned Behavior (Ajzen, 1985) to assess these intentions.

\section{Theory of Planned Behavior and Intent to Innovate}

We adopt the Theory of Planned Behavior, TPB for three reasons. First, it has been subjected to testing and the results offer strong statistical support of the model (Krueger et al., 2000). Second, it gives the opportunity to measure the development of intentions through entrepreneurship education. Third, it has been applied in other similar empirical studies (Mayhew et al., 2012).

The underlining assumption of this theory is that individuals have volitional control over their behavior; that intent predicts action: those with intention are more likely to perform the behavior than those without intention (Mayhew et al., 2012). Accordingly, this theory posits behavior as a function of intention and intention as a function of three elements: attitude towards entrepreneurship, subjective norms and perceived behavioral control (Ajzen, 1985). Attitude towards entrepreneurship refers to the degree of desirability of a certain behavior based on the expectations and beliefs about the personal impact of outcomes resulting from such behavior (Krueger et al., 2000). Subjective Norms refer to the social and cultural pressure to become an entrepreneur (Krueger et al., 2000). In other words, Perceived Behavioral Control overlaps with the concept of self-efficacy (Bandura, 1986); a measure of an individual's perceived ease or difficulty of becoming an entrepreneur (Krueger et al., 2000). Attitude, Subjective Norms, and behavioral control can be summarized respectively with these three questions: How desir- 
able is it to perform this behavior? How desirable do people close to the individual in question think it is to perform this behavior? Do I believe in my ability to perform this behavior? (Lorz, 2011). However, as seen in figure 1, our theoretical model does not include subjective norms, in part due to its traditionally insignificant role in TPB (see Peterman and Kennedy, 2003; Autio et al., 2001; Krueger et al., 2000) and because the beliefs of friends and family cannot be influenced directly by entrepreneurship education (Rauch and Hulsink, 2015).

INSERT FIGURE 1 AROUND HERE

\section{Intention to Innovate and its antecedents}

Human capital theory predicts that individuals with greater levels of knowledge, skills, and other competencies will achieve greater entrepreneurial outcomes than those who possess lower levels (Ratzinger et al., 2018; Mosey and Wright, 2007; Martin et al., 2013; Marvel and Lumpkin, 2007). Compulsory courses in entrepreneurship reportedly raise awareness, knowledge and skills regarding entrepreneurship (Dakung et al., 2017; Martinez et al., 2010). Therefore, one can deduce that compulsory entrepreneurship education elicits changes in entrepreneurial intentions. Although some studies of compulsory courses in entrepreneurship report negative impact on intention (Oosterbeek et al., 2010; von Graevenitz et al., 2010), overall, those studies are more than offset by the numerous studies that show positive impacts of entrepreneurship education on intention (Arranz et al., 2017; Nabi et al., 2018; Martinez et al., 2010; Rauch and Hulsink, 2015).

Moreover, empirical studies broadly confirm that attitudes towards entrepreneurship and perceived behavioral control mediate the effects of entrepreneurship education on intentions (Arranz et al., 2017; Rauch and Hulsink, 2015; Souitaris et al., 2007). However, to confirm whether this relationship is also true for innovative intentions in the Nigerian context, we suggest:

H1a Change in attitude towards the act of entrepreneurship positively relates to change in intention to innovate

H1b Change in attitude towards the act of entrepreneurship positively relates to change in entrepreneurial Intent 
H1c Change in perceived behavioral control positively relates to change in intent to innovate

H1d Change in perceived behavioral control positively relates to change in entrepreneurial intent

\section{Experiential Pedagogy: Engaging-Faculty and Out-of-Class Experience}

The three key elements of experiential pedagogy are engagement, action and reflection. Experiential pedagogy gives students opportunity(ies) to (a) engage - proactively participate in the learning, (b) take some form of action(s) - which constitutes concrete experience for them, (c) and reflect on their actions. Together these elements yield higher outcomes regarding cognitive skills (Kolb, 1984; Holman et al., 1996).

For this study, we posit experiential pedagogy as a function of out-of-class-experiences and engaging-faculty. Out-of-class experiences refer to co-curricular and extra-curricular activities which students participate outside a traditional classroom environment at the same time as their primary program of study (Mayhew et al., 2012). Students who participate in out-of-class experiences are more competent with higher levels of cognitive skills and self-management skills than those who do not (Sitra and Sasidhar, 2005). As a result, Mayhew et al. (2012) argue that out-of-class experiences provide opportunities to acquire further knowledge associated with becoming a confident businessperson. By connecting out-of-class experiences and inclass experiences, students can make combinations that may lead to innovative ideas (Arranz et al., 2017). Therefore, we argue that out-of-class experiences will be associated with changes in intent to innovate. Thus:

$\mathrm{H} 2 \mathrm{a}$ Out of Class experiences have positive effect on the change in attitude towards the act of entrepreneurship.

$\mathrm{H} 2 \mathrm{~b}$ Out of Class experiences have positive effect on the change in perceived behavioral control.

$\mathrm{H} 2 \mathrm{c}$ Out of Class experiences have positive effect on the change in Intention to innovate. 
$\mathrm{H} 2 \mathrm{~d}$ Out of Class experiences have positive effect on the change in entrepreneurial intent.

Engaging-faculty refers to faculty that creates a challenging learning environment where students challenge their ideas, think outside the box to solve problems, and are inspired to be innovative and creative (Mayhew et al., 2012). An example of engaging-faculty is a practicing entrepreneur in a classroom who shares his experiences of doing entrepreneurship. We consider engaging-faculty to be a reasonable and appropriate variable of experiential pedagogy especially in emerging countries where large class sizes, high student to staff ratio and low financial budgets characterize universities (WENR, 2017). Engaging-faculty is quicker, easier and cheaper to implement than out-of-class experiences (NSSE, 2014).

Engaging-faculty creates learning environments that break down the boundaries between the university and the outside world (Arranz et al., 2017); thereby inspires students to change their attitudes towards entrepreneurship and their beliefs about the availability of resources (Souitaris et al., 2007). As Souitaris et al. (2007) report, when students are inspired, the probability that they will pursue a career in ent1 leurship increases. This point is echoed by Dakung et al. (2017), who find that the more lecturers inspire students when teaching entrepreneurship, the more their entrepreneurial action. Based on this logic we propose the following hypotheses:

H2e Engaging faculty have positive effect on the change in attitude towards the act of entrepreneurship

H2f Engaging faculty have positive effect on the change in perceived behavioral control

$\mathrm{H} 2 \mathrm{~g}$ Engaging faculty have positive effect on the change in intent to innovate

$\mathrm{H} 2 \mathrm{~h}$ Engaging faculty have positive effect on the change in entrepreneurial intent

\section{Effect of University type -Public Versus Private University}

Evidence of the effects of type of university on entrepreneurial intention is mixed. Pihie et al. (2013) find that Malaysian students from private universities had higher entrepreneurial inten- 
tion than their counterparts from public universities. In contrast Canever et al. (2017) report that the university environment, whether public or private, discourages entrepreneurial intention. A plausible reason for these mixed evidences is that public universities use experiential pedagogy to a lesser extent than public universities, in part due to financial constraints and class sizes (Nkomo, 2015; George et al., 2016). In Brazil, for instance, private universities provide more opportunities for practical lessons in entrepreneurship than public universities (Perim, 2015). Because of the differences in the level of experiential pedagogy, ceteris paribus, changes in entrepreneurial attitudes, behavioral control and entrepreneurial intention and intentions to innovate after compulsory entrepreneurship course are likely to be higher in private universities than public universities (Dakung et al., 2017; Arranz et al., 2017; Mayhew et al., 2012). Thus, we hypothesize that:

H3a Students in Private Universities will have greater change in attitude towards the act of entrepreneurship after compulsory entrepreneurship education than students in Public universities.

H3b Students in Private Universities will have greater change in perceived behavioral control after compulsory entrepreneurship education than students in Public universities.

$\mathrm{H} 3 \mathrm{c}$ Students in Private Universities will have greater change in intent to innovate after compulsory entrepreneurship education than students in Public universities.

H3d Students in Private Universities will have greater change in entrepreneurial intent after compulsory entrepreneurship education than students in Public universities.

\section{METHOD}

The compulsory implementation of entrepreneurship throughout the Nigerian higher education sector means that students are subject to a 'natural experiment. We adopt a quantitative research approach with a pretest-posttest research design to investigate the changes in entrepreneurial intention and intent to innovate across private and public universities. Accordingly, we use a 
questionnaire to collect data and employ Structural Equation Modeling to conduct a path analysis and test hypotheses concerning the relationship between variables. Three reasons justify our approach. First, it is consistent with epistemological assumptions about the nature of intention. Second, the nature of the research questions is consistent with quantitative research. As Creswell points out, "quantitative research question inquire about the relationships among variables that the investigator seeks to know" (Creswell, 2013, p.143). Research questions one to three are about the relationship between variables education, pedagogy, intention, and its antecedents. Third, previous studies that have examined intention espouse quantitative research evidenced by testing hypothesis (see table 1). Moreover, our pretest-posttest design is consistent with our hypothesis of the changes in entrepreneurial intention and intent to innovate and their antecedents.

\section{INSERT TABLE 1 AROUND HERE}

\section{Sample Description and Data Collection}

Our sample is a randomly selected group of second-year students undertaking a compulsory entrepreneurship course at one public university - the University of Ibadan, and two private universities - Pan Atlantic University and Covenant University. The University of Ibadan had a student population of 26,783 , a student to staff ratio of $17: 1$; females to males ratio of $47: 53$ and $1 \%$ of international students (THE, 2018b). The average class size for the entrepreneurship course is 650 . Covenant University has a population of 9,411 students, $0 \%$ international students, student to staff ratio of 18:1 and female to male ratio of 37:63 (THE, 2018a). The average class size for the entrepreneurship is 1800. Pan-Atlantic University has a student population of 757 and a student to staff ratio of 11:1 (PAU, 2017). The class size for the entrepreneurship course is 66. Although the course, which takes place over one semester does not count towards students' GPA, students must pass it to graduate. The universities were selected because the authors were able to negotiate access through their contacts at the universities (Saunders et al., 2009). Each University has a business school and a dedicated center for entrepreneurship development that coordinates the entrepreneurship course across the university. All three universities reflect the common challenges faced by public and private universities such as class 
sizes and limited financial and infrastructural resources to support high levels of experiential pedagogy. These reasons increase the generalizability of our results beyond the universities we selected.

In the public university, the course is delivered mostly by academics from various disciplines within the university, while in the private universities, external and practicing entrepreneurs were invited to deliver some lectures. At the end of the course in the public university, students complete a multiple choice exam to assess their learning; whereas in the private universities, students complete an essay type assessment in the form of an exam. Besides, unlike the public university, the private universities engage students in practical entrepreneurial activities including student start-up exercise or skills acquisition activities.

Since our experiment was set up to capture the changes in the intention to innovate across public and private universities, we grouped the sample by university type and conducted two measurement waves (T1 \& T2) with it. Before data collection at T1, we conducted a pilot study with 5 academics and 90 non-participating students. The purpose of this was to ensure the clarity of working and face validity of constructs (Souitaris et al., 2007). We clearly explained to all surveyed students that the questionnaires were for research purposes only, participation was voluntary and personal information that will identify an individual, such as name and email address was not collect. For the first measurement wave (T1), questionnaires were distributed and collected on the same day during the second week of the course and repeated this one month after the end of the course for the second measurement wave (T2).

The total sample at T1 was 379 (235 in UI, 38 in PAU and 106 in CU); At time T2 more people were willing to complete our questionnaire. So we collected a total of 396 samples (219 in UI, 73 in PAU and 104 in CU) at T2. After data screening 24 were removed from T2 sample because they had missing data and unengaged responses reducing the sample size at T2 to 396. Using email, age, and gender, we were able to identify and match 361 samples (219 in UI, 38 in PAU, and 104 in CU) who completed our questionnaire both at T1 and T2. Both at time T1 and time $\mathrm{T} 2$, the questionnaire measured intentions and its antecedents (entrepreneurial intention, intention to innovate, attitudes, perceived behavioral control), and experiential pedagogy (which is a function of out-of-class experiences and engaged faculty). A follow-up assessment 
for entrepreneurial behavior was not feasible for this study, in part due to the limitation of time for the study and because the effects of entrepreneurship education on behavior are delayed (Kolvereid, 1996).

\section{Measures/ Variable Operationalization}

All our scales were tested for reliability and validity. Our data confirmed the reliability of all scales with $\alpha \succ 0.7$. Each scale had a minimum of 4 items and all of them loaded on a single factor in an exploratory factor analysis.

\section{Explained Variables}

Two explained variables for our study are Intent to Innovate and entrepreneurial intention.

Intent to innovate was measured by the extent to which people seriously considered to identify and pursue new business-related opportunities such as a new product or service that is not currently available or a more effective way of producing such product or providing such service. Four items from Mayhew et al. (2012) were used for this. These items were in a five-point 'Likert Scale' ranging from 'extremely ineffective' to 'extremely effective.' A sample item was 'please indicate how effective you are in ... identifying new opportunities (such as a new product or service a more effective way of accomplishing tasks, or a new way to solve a common social problem).' Our data confirmed the reliability of the scale (Cronbach's $\alpha=0.74$ at $\mathrm{t} 1$ and 0.84 at $\mathrm{t} 2$ ). All the items loaded on one factor in the EFA.

To assess entrepreneurial intention, we used six items from Liñán and Chen (2009). A sample was 'I am ready to do anything to be an entrepreneur.' Responses were given on a 7 point Likert scale from absolutely disagree to absolutely agree. Our data confirmed the reliability of the scale (Cronbach's $\alpha=0.90$ at $\mathrm{t} 1$ and 0.94 at $\mathrm{t} 2$ ).

\section{Explanatory Variables}

Attitude towards entrepreneurship was measured using five items from Liñán and Chen (2009). A sample question was 'Being an entrepreneur implies more advantages than disadvantages to 
me.' The responses were given on a 7-point scale. Our data confirmed the reliability of the scale (Cronbach's $\alpha=0.89$ at $\mathrm{t} 1$ and 0.92 at t2).

Perceived behavioral control was assessed by the extent to which people rate a business opportunity as feasible and feel they can influence the outcome (Rauch and Hulsink, 2015). We used four 7-point items from Liñán and Chen (2009). One item was 'I can control the creation process of a new firm.' The answers ranged from 1 to 7 . Our data confirmed the reliability of the scale (Cronbach's $\alpha=0.84$ at $\mathrm{t} 1$ and 0.88 at $\mathrm{t} 2$ ).

Two factors were assessed under experiential pedagogy. They were engaging-faculty and out-of-class-experiences. These factors were adapted from Mayhew et al. (2012) who described engaged engaging-faculty as 'Challenging Learning Environment' and out-of-classexperiences as 'Connecting experiences.' We change their names to reflect what they capture. Engaging-faculty was assessed using 5 items with the responses given on a 5 point scale from strongly disagree to strongly agree. An example question is 'Faculty challenge me to think outside of the box to create solutions to problems presented in class.' (Cronbach's $\alpha=0.84$ at $\mathrm{t} 1$ and 0.88 at t2). Out-of-class-experiences was assessed using four items from Mayhew et al. (2012). Items were based on a 5 point scale and responses ranged from 1 (strongly disagree) to 5 (strongly agree). A sample was 'My out-of-class experiences had a positive influence on my intellectual growth and ideas.' Our data confirmed the reliability of the scale (Cronbach's $\alpha=$ 0.84 at $\mathrm{t} 1$ and 0.88 at $\mathrm{t} 2$ ).

\section{Controls}

Various control variables were included in our measurement model to isolate the effect of our independent variables. First, we controlled for gender because previous studies have indicated that men are more likely to develop the intention to start a business venture than women (Brush, 1992; Kolvereid and Moen, 1997). Gender effects were captured with a dummy variable for being male $(1=$ male, $0=$ female $)$.

Second, we controlled for age because it has been related both to intentions (Morris and Venkatesh, 2000) and entrepreneurial behavior (Reynolds, 1987). Older individuals are less likely to engage in entrepreneurship because of increased levels of opportunity costs associated 
with it (Levesque and Minniti, 2006).

Third, entrepreneur kin can serve as role models (Scherer et al., 1989), serve as a source of entrepreneurial know-how (Tervo, 2006), and increase entrepreneurship behavior (Bosma et al., 2012; Chlosta et al., 2012). As Rauch and Hulsink (2015) note, there are several reasons why having entrepreneur kin might increase the probability that a given individual turns to entrepreneurship. Entrepreneur kin might offer informal induction in business methods, transfer business networks, consultancy and reputation. Furthermore, from the child's perspective, the potential of inheriting a family business might be a motivating factor to pursue entrepreneurship, for instance in agriculture where parents pass on their farms to their children. We, therefore, included two separate dummy variables for having an entrepreneur parent $(1=$ entrepreneur, $0=$ otherwise)

\section{INSERT TABLE 2 AROUND HERE}

\section{RESULTS}

We conducted a t-test to find out if there were significant differences between the group of students from private and public universities at T1 and T2 (see Table 2). At T1 there was a significant difference in the mean entrepreneurial intention $(\mathrm{p}<.05)$, attitude $(\mathrm{p}<.01)$, perceived behavioral control $(\mathrm{p}<.001)$, and intent to innovate $(\mathrm{p}<.05)$ between private and public universities. Also, public university students had higher values going into entrepreneurship course. However, at $\mathrm{T} 2$, none of the t-tests were significant, which indicates that groups were equivalent at the end of the course. Table 5 presents the descriptive statistics and correlations of the study variables.

\section{Test of Hypotheses}

Structural equation modeling (SEM) allows us to simultaneously combine factor analysis and linear regression models to test our hypothesis. Another benefit is the ability to test direct and indirect (mediating) effects in one model. We used the difference scores to derive the changes 
in entrepreneurial intention, intent to innovate, attitude, perceived behavioral control, Out-ofclass experiences, and Faculty-influence in our analyses. Our preference for difference score is in line with our hypotheses on changes in measured variables over time similar to Souitaris et al. (2007). We used the difference score of attitude and behavioral control as mediators in the relationship between university type -private vs. public, and entrepreneurial intention as well as intent to innovate.

Our specified model allowed us to test the effects of the changes in attitude and perceived behavioral control on entrepreneurial intent as well as intent to innovate (H1a-d). We also tested the direct effect of a change in the perception of out-of-class experiences on changes in attitude, perceived behavioral control, entrepreneurial intent, and intent to innovate (H2a-d); and the direct effect of changes in perception of engaged faculty on changes in attitude, perceived behavioral control, entrepreneurial intent and intent to innovate (H2e-h). Furthermore, we tested the direct effect of university type -private versus public on changes in attitude and perceived behavioral control $(\mathrm{H} 3 \mathrm{a}-\mathrm{b})$; as well as on entrepreneurial and innovative intentions $(\mathrm{H} 3 \mathrm{c}-\mathrm{d})$. Finally, tested the indirect effect of university type on entrepreneurial intention and intention to innovate. We controlled for gender, age, and entrepreneurial kin.

INSERT TABLE 3 AROUND HERE

To evaluate the fit of our model, we used the root mean square error of approximation (RMSEA), the square root mean residual (SRMR) and the comparative fit index (CFI) (Hair et al., 2010). A model can be considered to have a good fit if the CFI value exceeds .95, the RMSEA is below .06, and the SRMR is smaller than .08. A good configural invariance (Steenkamp and Baumgartner, 1998) was obtained as evidenced by adequate goodness of fit when private and public universities groups are tested together and freely (RMSEA $=.04$, SRMR $=.05$; and CFI $=.95)$. Also, Chi-square $\left(X^{2}\right)$ difference test between a fully constrained and unconstrained model indicates that the private and public university students groups are invariant $(p=.123)$.

The result of our model (see Figure 2 and Table 3) showed a good fit: $X^{2}(9)=13.44$; RM$\mathrm{SEA}=.04 ; \mathrm{CFI}=1.00 ; \mathrm{SRMR}=.03$. We examined the path coefficients to test our hypothesis according to our theoretical model. We found significant effects which support H1b-d. Specif- 
ically, we found that change in attitude positively affects change in entrepreneurial intention ( $\beta$ $=.41, \mathrm{p}<.001)$; change in behavioral control had a positive effect on change in entrepreneurial intention $(\beta=.36, \mathrm{p}<.001)$; change in behavioral control also had a positive effect on change in intent to innovate $(\beta=.54 \mathrm{p}<.001)$. We did not find a significant effect for the relationship between change in attitude and change in intent to innovate $(\beta=.10$, ns). Hence H1a was not supported. With regards to the effect of the change in out-of-class experience, we found significant and positive effects on change in attitude $(\beta=.30, \mathrm{p}<.001)$; change in behavioral control $(\beta=.17, \mathrm{p}<.001)$; change in intention to innovate $(\beta=.19, \mathrm{p}<.001)$. We did not find any significant effect for change in out-of-classroom on entrepreneurial intention $(\beta=-.02$, ns). Therefore $\mathrm{H} 2 \mathrm{a}-\mathrm{c}$ were supported but $\mathrm{H} 2 \mathrm{~d}$ was not supported. Change in perception of engaged-faculty significantly and positively affected the change in attitude $(\beta=.13, \mathrm{p}<.001)$ and change in behavioral control $(\beta=.31, \mathrm{p}<.05)$. Surprisingly, we did not find any direct effect of faculty-influence on change of entrepreneurial intention $(\beta=.00$, ns) and change in intent to innovate $(\beta=-.03$, ns). Thus $\mathrm{H} 2 \mathrm{e}-\mathrm{f}$ were supported while $\mathrm{H} 2 \mathrm{~g}-\mathrm{h}$ were not supported. We found evidence that students in private universities had greater increase in attitude $(\beta=.15$, $\mathrm{p}<.01)$ as well as behavioral control $(\beta=.12, \mathrm{p}<.05)$ than their comparable counterparts in the public university after undertaking compulsory entrepreneurship education. However, we did not find any evidence that students in private universities will develop higher entrepreneurial intention $(\beta=.00, \mathrm{~ns})$ and intent to innovate $(\beta=-.06, \mathrm{~ns})$ than those in public university. Thus, the results show support for $\mathrm{H} 3 \mathrm{a}-\mathrm{b}$ but not for $\mathrm{H} 3 \mathrm{c}-\mathrm{d}$. Because all the paths in the structural model have statistical power of 1.00 , we are confident that if there is a significant effect, there is a $100 \%$ chance that it would have been detected.

Although H3c-d was not supported we calculated the indirect effect of private versus public variable on the change in entrepreneurial intention and intent to innovate. Furthermore, we found an indirect effect of university type (private versus public) on change in entrepreneurial intention (indirect effect: .18, $\mathrm{p}<.05$ ) and change in intent to innovate (indirect effect: .11, $\mathrm{p}<$ .05) through the change in behavioral control. Also, we found an indirect effect of university type (private versus public) on change in entrepreneurial intention (indirect effect: .26, $\mathrm{p}<.01$ ) through the change in attitude. Rather than a direct effect, the results show that engaged faculty 
have indirect effect on intention to innovate $(\beta=.14, \mathrm{p}<.01)$ and entrepreneurial intention $(\beta=.23, \mathrm{p}<.01)$ behavioral control. Out-of-class experiences also have indirect effect on entrepreneurial intention through attitude $(\beta=.26, \mathrm{p}<.01)$. See table 4 for a complete list of the indirect effects.

INSERT FIGURE 2 AROUND HERE

\section{DISCUSSION}

Our objective in this study was to address three research questions: 1) Does compulsory entrepreneurship education affect students' intent to innovate? 2) Can experiential pedagogy influence intent to innovate? 3) Does the impact of compulsory entrepreneurship education vary across private versus public universities? To address these questions, we developed a model based on the theory of planned behavior. Our study showed that out-of-class experiences can play a critical role in the development of intention to innovate in compulsory entrepreneurship education regardless of of the university type. Contrary to our hypothesis, students in private universities do not develop higher intention to innovate than those in public universities after completing compulsory entrepreneurship education. However, students from private universities experience a greater change in their attitude and behavioral control than those in public universities after entrepreneurship education. One can conclude, as (Canever et al., 2017) and (Perim, 2015) conclude with regards to entrepreneurial intention, that the public university dampens attitude towards entrepreneurship and behavioral control while private university strengthens them. But such conclusion disregards the role of other factors in entrepreneurship education. One of such factors that is more likely than not, Ceteris paribus, to explain why students in private university have greater attitude and behavioral control than their counterparts in public universities is experiential pedagogy. The structural model shows that experiential pedagogy (which is constructed in our study as out-of-class-experiences and engaged-faculty) indirectly raises entrepreneurial intention of all students. Both out-of-class-experiences and engaged-faculty were used more in private universities than in public universities. As Nabi et al. (2017) conclude, experientially based teaching methods have stronger impact regarding 
entrepreneurial intention. In other words, "more experiential pedagogies seem to have the most potential to have impact at higher levels because students focus on developing behavioral competency in solving problems in real-life entrepreneurial situations" (Nabi et al., 2017, p. 292).

The mixed evidence of the impact of compulsory entrepreneurship education we present have several theoretical and practical implications.

\section{Theoretical Contributions}

First, our study extends entrepreneurship education theory by highlighting the effects of context and pedagogy on innovative intentions (see Arranz et al., 2017; Gielnik et al., 2015; Mayhew et al., 2012; Baumol et al., 2009). To our knowledge, we present the first study to investigate the intent to innovate as an innovative outcome of entrepreneurship education using the theory of planned behavior. Our results provide evidence of the decisive role of experiential pedagogy in the development of innovative intentions which is a precursor to innovative entrepreneurship. Similar to the results of Arranz et al. (2017) we find that out of class experiences increase attitude and behavioral control towards entrepreneurship. Our findings extend their research by providing evidence that out of class experiences directly stimulates intent to innovate. Also, in line with Souitaris et al. (2007) our study shows that engaging-faculty directly inspires change in attitude towards entrepreneurship. We extend their research with evidence that engagingfaculty indirectly inspires intent to innovate through changes in students' behavioral control. However, we did not find a direct impact of out-of-class experiences on entrepreneurial intention.

Second, our results also contribute to the theory of planned behavior by demonstrating that attitude and behavioral control are mediators of the effect of compulsory entrepreneurship education on changes in entrepreneurial intention, and that perceived behavioral control is a mediating variable that can also help to explain intention to innovate. The evidence is consistent with Autio et al. (2001) who found that perceived behavioral control has the strongest relationship with intentions but contrary to Rauch and Hulsink (2015) who did not find the mediator effects of perceived behavioral control.

Third, our study also contributes to experiential learning theory. The ethos of experiential 
learning is that learning by doing is the best way to learn (Dewey and Small, 1897). Learning should be active, practical as well as theoretical not just passive and theoretical (Neck et al., 2014; Rasmussen and Sørheim, 2006). We show that active learning methods such as outof-class experiences which provide opportunities for action and reflection help to transform experiences into knowledge (Kolb, 1984) that supports innovative outcomes.

Fourth, by providing evidence of the direct effect of out-of-class experiences on intention to innovate, and the indirect effect of engaging-faculty, our study makes valuable contribution to the conversation about how to train innovative entrepreneurs (Baumol, 2004; Rasmussen and Sørheim, 2006). Innovative intentions are the precursor to innovative entrepreneurship both at the firm, regional and national level. Innovative entrepreneurs will introduce new products, services, and processes that will ensure high economic growth (Mosey et al., 2017). As Baumol et al. (2009) note innovative entrepreneurs - those who focus on the introduction and acceptance of new products and new production methods, require a change in strategy of curriculum and pedagogy from other types of entrepreneurs. Learning how to train these entrepreneurs is a vital step in this process of cultivating innovative entrepreneurship.

Furthermore, similar to Canever et al. (2017), we did not find evidence that students in private universities will develop more or less intention to innovate than those in public universities after compulsory entrepreneurship course. This finding is encouraging because it suggests that the differences in socioeconomic backgrounds of students, staff-to-student ratio and other resources constraints at public and private universities may have no bearing with entrepreneurial intention or intent to innovate. Instead, as evidenced by our study, the higher the use of out-ofclass activities, the higher the innovative intentions regardless of contextual factors.

Finally, in line with Souitaris et al. (2007) our study shows that engaging-faculty indirectly inspires intent to innovate through changes in students' behavioral control. They also inspire change in attitude towards entrepreneurship. Inspiration (a construct with an emotional element) change 'hearts and minds' and increases the likelihood that students will attempt innovative entrepreneurship at some point in their lives (Souitaris et al., 2007). Therefore, we echo the remarks of Arranz et al. (2017) that entrepreneurship educators should be, to some extent, entrepreneurs because they draw from real life experiences when teaching. Students perceive 
this teaching highly inspiring because it breaks down the boundaries between the university and the outside world.

\section{Practical Implications}

Based on the evidence of the impact of out-of-class activities, educators should pay more attention to opportunities that will take learning outside the classroom to cultivate innovative intentions. For instance, entrepreneurship courses can include field trips, student start-up projects, business plan competitions, computer simulations, cooperative group work, collaborative learning outside classrooms. Other low-cost out-of-class activities that can be implemented with large student populations include online chat forums, the use of video and films, and student entrepreneurship clubs (Solomon, 2007). These practices allow students to connect the dots between theory and practice, stimulate innovative ideas and maximize the development of innovative intentions (Arranz et al., 2017).

It is essential to note that compulsory entrepreneurship courses may conflict with the requirements of main courses which may discourage some students from actively participating in the course. We recommend that students should be incentivized to participate in this course by introducing opportunities for practicing and applying their knowledge through various entrepreneurship competition. We note that the implementation of experiential pedagogy is resource intensive (Rasmussen and Sørheim, 2006), so to cultivate innovative entrepreneurship, policymakers may invest in promoting out-of-class-experiences and training faculty to engage students in the classroom more.

\section{LIMITATION AND RECOMMENDATIONS}

When interpreting our result, one must have to take into account that the studied participants are within a single context. Intention models have been tested in different countries and have been replicated in different contexts (Liñán and Chen, 2009). There are regional and cross-country differences in entrepreneurial intention (Nowiński et al., 2017; Bae et al., 2014). However, the fact that we used quantitative pretest-posttest research design increases the generalizability of our findings. Future studies may replicate our study in other developing country context to 
confirm or disconfirm our findings. Besides, our study focuses on intention to innovate which may translate to innovative entrepreneurship (Greene and Saridakis, 2008). However, people with innovative intent may not pursue innovative entrepreneurship any more than will people with entrepreneurial intent become entrepreneurs. After all, entrepreneurs are constrained by the entrepreneurship degree of freedom (Wilson and Martin, 2015). Future studies should, therefore, employ longitudinal design over a longer period to investigate whether innovative intentions translate to innovative entrepreneurship.

\section{CONCLUSION}

Our study shows, in the Nigeria context, that out-of-class experiences transcend the contextual factors such as the type of course and type of university to increase the intentions to innovate of all students. Therefore, if policymakers in similar regions want to increase the levels of intentions to innovate, they should promote out-of-class activities. Second, we provide evidence that engaging-faculty increases the changes in attitude towards entrepreneurship and perceived behavioral control. Therefore, entrepreneurship educators should engage students in the learning process for higher impact to occur. Last, our study did not find any evidence that compulsory courses in entrepreneurship enhance the intentions of students in private universities more than those in public universities: thereby contributing to the debate of the relative efficacy of pedagogy versus resources for impactful entrepreneurship education.

\section{References}

Acs, Z. (2006). How is entrepreneurship good for economic growth? Innovations, 1(1):97-107. Ajzen, I. (1985). From Intentions to Actions: A Theory of Planned Behavior. Springer.

Arranz, N., Ubierna, F., Arroyabe, M. F., Perez, C., and Fdez. de Arroyabe, J. (2017). The effect of curricular and extracurricular activities on university students' entrepreneurial intention and competences. Studies in Higher Education, 42(11):1979-2008.

Autio, E., H. Keeley, R., Klofsten, M., GC Parker, G., and Hay, M. (2001). Entrepreneurial intent among students in scandinavia and in the usa. Enterprise and Innovation Management Studies, 2(2):145-160.

Bae, T. J., Qian, S., Miao, C., and Fiet, J. O. (2014). The relationship between entrepreneurship education and entrepreneurial intentions: A meta-analytic review. Entrepreneurship Theory and Practice, 38(2):217-254. 
Bandura, A. (1986). Social foundations of thought and action: A social-cognitive view.

Baumol, W. J. (2004). Education for innovation: Entrepreneurial breakthroughs vs. corporate incremental improvements. Technical report, National Bureau of Economic Research.

Baumol, W. J., Schilling, M. A., and Wolff, E. N. (2009). The superstar inventors and entrepreneurs: How were they educated? Journal of Economics \& Management Strategy, 18(3):711-728.

Birch, D. G. (1979). The job generation process.

Bosma, N., Acs, Z. J., Autio, E., Coduras, A., and Levie, J. (2008). Global entrepreneurship monitor. Executive Report.

Bosma, N., Hessels, J., Schutjens, V., Van Praag, M., and Verheul, I. (2012). Entrepreneurship and role models. Journal of Economic Psychology, 33(2):410-424.

Brush, C. G. (1992). Research on women business owners: Past trends, a new perspective and future directions. Small Business: Critical Perspectives on Business and Management, pages $1038-70$.

Canever, M. D., Barral, M. R. M., and Ribeiro, F. G. (2017). How does the public and private university environment affect students' entrepreneurial intention? Education+ Training, 59(6).

Chlosta, S., Patzelt, H., Klein, S. B., and Dormann, C. (2012). Parental role models and the decision to become self-employed: The moderating effect of personality. Small Business Economics, 38(1):121-138.

Creswell, J. (2013). Research Design: Qualitative, Quantitative, and Mixed Method Approaches. SAGE Publications, Incorporated.

Dakung, R. J., Orobia, L., Munene, J. C., and Balunywa, W. (2017). The role of entrepreneurship education in shaping entrepreneurial action of disabled students in nigeria. Journal of Small Business \& Entrepreneurship, 29(4):293-311.

Davidsson, P. (2007). Method challenges and opportunities in the psychological study of entrepreneurship. The Psychology of Entrepreneurship, 287323.

Dewey, J. and Small, A. W. (1897). My Pedagogic Creed. Number 25. EL Kellogg \& Company.

Fayolle, A., Gailly, B., and Lassas-Clerc, N. (2006). Assessing the impact of entrepreneurship education programmes: A new methodology. Journal of European Industrial Training, 30(9):701-720.

George, G., Corbishley, C., Khayesi, J. N., Haas, M. R., and Tihanyi, L. (2016). Bringing africa in: Promising directions for management research. Academy of Management Journal, 59(2):377-393.

Gielnik, M. M., Frese, M., Kahara-Kawuki, A., Katono, I. W., Kyejjusa, S., Ngoma, M., Munene, J., Namatovu-Dawa, R., Nansubuga, F., Orobia, L., et al. (2015). Action and actionregulation in entrepreneurship: Evaluating a student training for promoting entrepreneurship. Academy of Management Learning \& Education, 14(1):69-94.

Greene, F. J. and Saridakis, G. (2008). The role of higher education skills and support in graduate self-employment. Studies in Higher Education, 33(6):653-672.

Greene, P. G., Katz, J. A., and Johannisson, B. (2004). From the guest co-editors. 
Hair, J., Black, W., and Babin, B. (2010). Multivariate Data Analysis: A Global Perspective. Global Edition. Pearson Education.

Hartnett, T. (2000). Financing trends and expenditure patterns in nigerian federal universities: An update. Background Study for the Nigerian University System Innovation Project, World Bank, Washington, Dc.

Holman, D., Pavlica, K., and Thorpe, R. (1996). Rethinking kolb's theory of experiential learning: The contribution of social construction \& activity theory. Management Learning, 4(24):485-504.

Hytti, U., Stenholm, P., Heinonen, J., and Seikkula-Leino, J. (2010). Perceived learning outcomes in entrepreneurship education: The impact of student motivation and team behaviour. Education+ Training, 52(8/9):587-606.

Kolb, D. A. (1984). Experiential Learning: Experience As the Source of Learning and Development, volume 1. Prentice-Hall Englewood Cliffs, NJ.

Kolvereid, L. (1996). Prediction of employment status choice intentions. Entrepreneurship: Theory and Practice, 21(1):47-58.

Kolvereid, L. and Moen, Ø. (1997). Entrepreneurship among business graduates: Does a major in entrepreneurship make a difference? Journal of European Industrial Training, 21(4):154160.

Krueger, N. F., Reilly, M. D., and Carsrud, A. L. (2000). Competing models of entrepreneurial intentions. Journal of Business Venturing, 15(5):411-432.

Levesque, M. and Minniti, M. (2006). The effect of aging on entrepreneurial behavior. Journal of Business Venturing, 21(2):177-194.

Li, J., Wu, S., and Wu, L. (2008). The impact of higher education on entrepreneurial intentions of university students in china. Journal of Small Business and Enterprise Development, 15(4):752-774.

Liñán, F. and Chen, Y.-W. (2009). Development and cross-cultural application of a specific instrument to measure entrepreneurial intentions. Entrepreneurship Theory and Practice, 33(3):593-617.

Lorz, M. (2011). The Impact of Entrepreneurship Education on Entrepreneurial Intention. $\mathrm{PhD}$ thesis, University of St. Gallen.

Lumpkin, G. T. and Dess, G. G. (1996). Clarifying the entrepreneurial orientation construct and linking it to performance. Academy of Management Review, 21(1):135-172.

Lüthje, C. and Franke, N. (2003). The 'making' of an entrepreneur: Testing a model of entrepreneurial intent among engineering students at mit. $R \& d$ Management, 33(2):135-147.

Martin, B. C., McNally, J. J., and Kay, M. J. (2013). Examining the formation of human capital in entrepreneurship: A meta-analysis of entrepreneurship education outcomes. Journal of Business Venturing, 28(2):211-224.

Martinez, A. C., Levie, J., Kelley, D. J., Saemundsson, R. J., and Schott, T. (2010). Global entrepreneurship monitor special report: A global perspective on entrepreneurship education and training. Global Entrepreneurship Monitor, United States.

Marvel, M. R. and Lumpkin, G. T. (2007). Technology entrepreneurs' human capital and its effects on innovation radicalness. Entrepreneurship Theory and Practice, 31(6):807-828. 
Mayhew, M. J., Simonoff, J. S., Baumol, W. J., Wiesenfeld, B. M., and Klein, M. W. (2012). Exploring innovative entrepreneurship and its ties to higher educational experiences. $R e$ search in Higher Education, 53(8):831-859.

Mentoor, E. and Friedrich, C. (2007). Is entrepreneurial education at south african universities successful? an empirical example. Industry and Higher Education, 21(3):221-232.

Morris, M. G. and Venkatesh, V. (2000). Age differences in technology adoption decisions: Implications for a changing work force. Personnel Psychology, 53(2):375-403.

Mosey, S., Guerrero, M., and Greenman, A. (2017). Technology entrepreneurship research opportunities: Insights from across europe. The Journal of Technology Transfer, 42(1):1-9.

Mosey, S. and Wright, M. (2007). From human capital to social capital: A longitudinal study of technology-based academic entrepreneurs. Entrepreneurship Theory and Practice, 31(6):909-935.

Nabi, G., Liñán, F., Fayolle, A., Krueger, N., and Walmsley, A. (2017). The impact of entrepreneurship education in higher education: A systematic review and research agenda. Academy of Management Learning \& Education, 16(2):277-299.

Nabi, G., Walmsley, A., Liñán, F., Akhtar, I., and Neame, C. (2018). Does entrepreneurship education in the first year of higher education develop entrepreneurial intentions? the role of learning and inspiration. Studies in Higher Education, 43(3):452-467.

NBS (2017). Labor force statistics vol. 1: Unemployment and underemployment report. techreport Q1-Q3, National Bureau of Statistics.

Neck, H. M. and Greene, P. G. (2011). Entrepreneurship education: Known worlds and new frontiers. Journal of Small Business Management, 49(1):55-70.

Neck, H. M., Greene, P. G., and Brush, C. G. (2014). Teaching Entrepreneurship: A Practicebased Approach. Edward Elgar Publishing.

Nkomo, S. M. (2015). Challenges for management and business education in a "developmental" state: The case of south africa. Academy of Management Learning \& Education, 14(2):242258.

Nowiński, W., Haddoud, M. Y., Lančarič, D., Egerová, D., and Czeglédi, C. (2017). The impact of entrepreneurship education, entrepreneurial self-efficacy and gender on entrepreneurial intentions of university students in the visegrad countries. Studies in Higher Education, pages 1-19.

NSSE (2014). Nsse annual results 2014: Bringing the institution into focus.

Oosterbeek, H., van Praag, M., and Ijsselstein, A. (2010). The impact of entrepreneurship education on entrepreneurship skills and motivation. European Economic Review, 54(3):442454.

PAU (2017). 2016/2017 annual report. Technical report, Pan-African University.

Perim, M. L. S. (2015). Comparação do ensino e da prática de empreendedorismo em instituições de ensino superior públicas e privadas de boa vista. Revista De Administração De Roraima-rarr, 2(1):67-87.

Peterman, N. E. and Kennedy, J. (2003). Enterprise education: Influencing students' perceptions of entrepreneurship. Entrepreneurship Theory and Practice, 28(2):129-144. 
Pihie, Z. A. L., Bagheri, A., and Sani, Z. H. A. (2013). Knowledge of cognition and entrepreneurial intentions: Implications for learning entrepreneurship in public and private universities. Procedia-social and Behavioral Sciences, 97:174-181.

Pittaway, L. and Cope, J. (2007). Entrepreneurship education a systematic review of the evidence. International Small Business Journal, 25(5):479-510.

Rasmussen, E. A. and Sørheim, R. (2006). Action-based entrepreneurship education. Technovation, 26(2):185-194.

Ratzinger, D., Amess, K., Greenman, A., and Mosey, S. (2018). The impact of digital startup founders' higher education on reaching equity investment milestones. The Journal of Technology Transfer, 43(3):760-778.

Rauch, A. and Hulsink, W. (2015). Putting entrepreneurship education where the intention to act lies: An investigation into the impact of entrepreneurship education on entrepreneurial behavior. Academy of Management Learning \& Education, 14(2):187-204.

Reynolds, P. D. (1987). New firms: Societal contribution versus survival potential. Journal of Business Venturing, 2(3):231-246.

Saunders, M., Lewis, P., and Thornhill, A. (2009). Research Methods for Business Students. Always learning. Financial Times Prentice Hall.

Scherer, R. F., Adams, J. S., Carley, S., and Wiebe, F. A. (1989). Role model performance effects on development of entrepreneurial career preference.

Shane, S. and Venkataraman, S. (2000). The promise of entrepreneurship as a field of research. Academy of Management Review, 25(1):217-226.

Sitra, A. R. A. and Sasidhar, B. (2005). Teachers' perception on the effectiveness of cocurricular activities: A case study of malaysian schools. Unitar E-journal, 1(1):32.

Solomon, G. (2007). An examination of entrepreneurship education in the united states. Journal of Small Business and Enterprise Development, 14(2):168-182.

Solomon, G. and Matlay, H. (2008). The impact of entrepreneurship education on entrepreneurial outcomes. Journal of Small Business and Enterprise Development, 15(2):382396.

Souitaris, V., Zerbinati, S., and Al-Laham, A. (2007). Do entrepreneurship programmes raise entrepreneurial intention of science and engineering students? the effect of learning, inspiration and resources. Journal of Business Venturing, 22(4):566-591.

Steenkamp, J.-B. E. and Baumgartner, H. (1998). Assessing measurement invariance in crossnational consumer research. Journal of Consumer Research, 25(1):78-90.

Tervo, H. (2006). Regional unemployment, self-employment and family background. Applied Economics, 38(9):1055-1062.

Thaddeus, E. (2012). Perspectives: Entrepreneurship development \& growth of enterprises in nigeria. Entrepreneurial Practice Review, 2(2):31-35.

THE (2018a). Covenant university world university rankings I the. (Accessed on 08/04/2018).

THE (2018b). University of ibadan world university rankings I the. (Accessed on 08/04/2018).

Thompson, E. R. (2009). Individual entrepreneurial intent: Construct clarification and development of an internationally reliable metric. Entrepreneurship Theory and Practice, 33(3):669694. 
Van Praag, C. M. and Versloot, P. H. (2007). What is the value of entrepreneurship? a review of recent research. Small Business Economics, 29(4):351-382.

von Graevenitz, G., Harhoff, D., and Weber, R. (2010). The effects of entrepreneurship education. Journal of Economic Behavior \& Organization, 76(1):90-112.

WENR (2017). Education in nigeria. http://wenr.wes.org/2017/03/education-in-nigeria. (Accessed on 10/26/2018).

Wilson, N. and Martin, L. (2015). Entrepreneurial opportunities for all? entrepreneurial capability and the capabilities approach. The International Journal of Entrepreneurship and Innovation, 16(3):159-169.

Zhang, Y., Duysters, G., and Cloodt, M. (2014). The role of entrepreneurship education as a predictor of university students' entrepreneurial intention. International Entrepreneurship and Management Journal, 10(3):623-641. 


\section{Tables and Figures}

Table 1: Philosophical Worldview, Design and Methods of Related Studies

\begin{tabular}{|c|c|c|c|c|}
\hline Article & $\begin{array}{l}\text { Philosophical } \\
\text { Worldview }\end{array}$ & Design & Method & Relationships Investigated \\
\hline $\begin{array}{l}\text { Rauch and } \\
\text { Hulsink } \\
(2015)\end{array}$ & $\begin{array}{c}\text { Post-positivism } \\
\text { (suggests intention is } \\
\text { an objective } \\
\text { phenomena that can } \\
\text { be measured) }\end{array}$ & $\begin{array}{c}\text { Quantitative } \\
\text { Hypothesis } \\
\text { Quasi Experiment } \\
\text { (Pre-post test } \\
\text { Comparison) }\end{array}$ & $\begin{array}{l}\text { Hypothesis testing } \\
\text { Survey } \\
\text { Sample size of } 153 \\
\text { pre-test, } 142 \text { post test }\end{array}$ & $\begin{array}{l}\text { Entrepreneurship Education } \\
\text { on Attitude towards } \\
\text { Entrepreneurship, Perceived } \\
\text { Behavioral control, Intention } \\
\text { and Entrepreneurial Behavior }\end{array}$ \\
\hline $\begin{array}{l}\text { Gielnik } \\
\text { et al. } \\
\text { (2015) }\end{array}$ & Post-positivist & Quantitative & $\begin{array}{l}\text { Survey and interview. } \\
\text { Sample size of } 384\end{array}$ & $\begin{array}{l}\text { Action-Based } \\
\text { Entrepreneurship Training on } \\
\text { business opportunity } \\
\text { identification, entrepreneurial } \\
\text { action and business creation }\end{array}$ \\
\hline $\begin{array}{l}\text { Mayhew } \\
\text { et al. } \\
(2012)\end{array}$ & Post-positivist & Quantitative & $\begin{array}{c}\text { Survey } \\
\text { sample size } 3700\end{array}$ & $\begin{array}{l}\text { Entrepreneurship course and } \\
\text { pedagogical strategies and } \\
\text { their links to intention to } \\
\text { innovate }\end{array}$ \\
\hline $\begin{array}{l}\text { Marvel and } \\
\text { Lumpkin } \\
\text { (2007) }\end{array}$ & $\begin{array}{c}\text { Post-positivism } \\
\text { (views opportunity as } \\
\text { an objective } \\
\text { phenomena - } \\
\text { "Recognizing } \\
\text { opportunities is often } \\
\text { like solving puzzles") }\end{array}$ & $\begin{array}{l}\text { Quantitative } \\
\text { Hypothesis }\end{array}$ & $\begin{array}{l}\text { Hypothesis testing } \\
\text { Survey } \\
\text { Sample size } 145\end{array}$ & $\begin{array}{c}\text { Technology Entrepreneurs' } \\
\text { Human Capital -Education, } \\
\text { experience and prior } \\
\text { knowledge, effects on } \\
\text { innovation radicalness }\end{array}$ \\
\hline $\begin{array}{l}\text { Pihie et al. } \\
\text { (2013) }\end{array}$ & $\begin{array}{l}\text { Post-positivism } \\
\text { (examined causal } \\
\text { relationship between } \\
\text { cognition and } \\
\text { intention) }\end{array}$ & Quantitative & $\begin{array}{c}\text { Survey } \\
\text { Sample size } 722\end{array}$ & $\begin{array}{l}\text { Knowledge of cognition and } \\
\text { entrepreneurial intentions } \\
\text { across public and private } \\
\text { university }\end{array}$ \\
\hline $\begin{array}{l}\text { Fayolle } \\
\text { et al. } \\
(2006)\end{array}$ & $\begin{array}{l}\text { Post-positivist/ } \\
\text { Pragmatist }\end{array}$ & $\begin{array}{l}\text { Quantitative } \\
\text { Experiment }\end{array}$ & $\begin{array}{l}\text { Questionnaire } \\
\text { Pilot study with } 20 \\
\text { students }\end{array}$ & $\begin{array}{l}\text { Entrepreneurship Education } \\
\text { on Attitude towards } \\
\text { Entrepreneurship, Perceived } \\
\text { Behavioral control, intention }\end{array}$ \\
\hline $\begin{array}{l}\text { Oosterbeek } \\
\text { et al. } \\
(2010)\end{array}$ & Post-positivism & $\begin{array}{l}\text { Quantitative } \\
\text { Pre and post }\end{array}$ & Survey and EScan ${ }^{1}$ & $\begin{array}{l}\text { Entrepreneurship education } \\
\text { on entrepreneurship skills } \\
\text { and entrepreneurial intention }\end{array}$ \\
\hline $\begin{array}{l}\text { Solomon } \\
\text { and Matlay } \\
\text { (2008) }\end{array}$ & $\begin{array}{l}\text { Constructivist/ } \\
\text { Interpretivist }\end{array}$ & Qualitative & $\begin{array}{l}\text { Semi-structured, } \\
\text { in-depth telephone } \\
\text { interviews of } 64 \\
\text { graduate } \\
\text { entrepreneurs }\end{array}$ & $\begin{array}{l}\text { Entrepreneurship education } \\
\text { on entrepreneurial outcomes }\end{array}$ \\
\hline $\begin{array}{l}\text { Li et al. } \\
(2008)\end{array}$ & Post-positivist & Quantitative & $\begin{array}{l}\text { Hypothesis testing } \\
\text { Questionnaire } \\
\text { Structural equation } \\
\text { modeling }\end{array}$ & $\begin{array}{c}\text { Higher education on } \\
\text { entrepreneurial intentions }\end{array}$ \\
\hline $\begin{array}{l}\text { Lüthje and } \\
\text { Franke } \\
(2003) \\
\end{array}$ & Post-positivist & Quantitative & $\begin{array}{c}\text { Survey } \\
\text { Sample size } 512\end{array}$ & $\begin{array}{l}\text { Personal traits on Attitude } \\
\text { towards Entrepreneurship and } \\
\text { entrepreneurial intention }\end{array}$ \\
\hline
\end{tabular}

${ }^{1}$ Escan is a validated self-assessment test based on 114 items (questions and statements) posed to individuals Oosterbeek et al. (2010). 
Table 2: T-Test of Private versus Public University

\begin{tabular}{|c|c|c|c|c|c|c|c|c|c|c|c|c|c|c|}
\hline \multirow[b]{2}{*}{ Variables } & \multicolumn{7}{|c|}{$\mathrm{T} 1$} & \multicolumn{7}{|c|}{ T2 } \\
\hline & $M P u b$ & M Priv & $M D$ & SD Pub & SD Priv & $t$ & & $M P u b$ & $M$ Priv & $M D$ & SDPub & SD Priv & $t$ & \\
\hline Intent to Innovate & .09 & -.14 & .24 & .88 & .89 & 2.50 & ${ }^{*}$ & .04 & -.06 & .11 & .94 & .89 & 1.07 & ns \\
\hline Attitute towards the Act & .12 & -.19 & .32 & .84 & 1.09 & 3.10 & ${ }^{* *}$ & -.05 & .08 & -.13 & 1.01 & .92 & -1.27 & ns \\
\hline \multirow[t]{4}{*}{ Percieved Behavioral Control } & .14 & -.22 & .37 & .92 & .91 & 3.70 & ${ }^{* * *}$ & .00 & .00 & -.01 & .98 & .91 & -.06 & ns \\
\hline & \multicolumn{9}{|c|}{ Paired T-test - Mean Differences Scores Between Two Periods T1 and T2 } & & & & & \\
\hline & \multirow{2}{*}{\multicolumn{9}{|c|}{$\begin{aligned} & M=\text { Mean } ; M D=\text { Mean Difference; } \text { Pub }=\text { Private University } ; \text { Priv }=\text { Private University } \\
&$\[ * \mathrm{p}<.05 ; * * \mathrm{p}<.01 ; * * * \mathrm{p}<001 \]$\end{aligned}$}} & & & & & \\
\hline & & & & & & & & & & & & & & \\
\hline \multicolumn{15}{|c|}{$\begin{array}{l}\text { Private university students had significantly lower PBC ATA, EI and Intent to Innovate at the beginning. This difference vanished at the end of the course. The overal drop in intention and its } \\
\text { antecedents was stronger in public university than in private universities }\end{array}$} \\
\hline
\end{tabular}




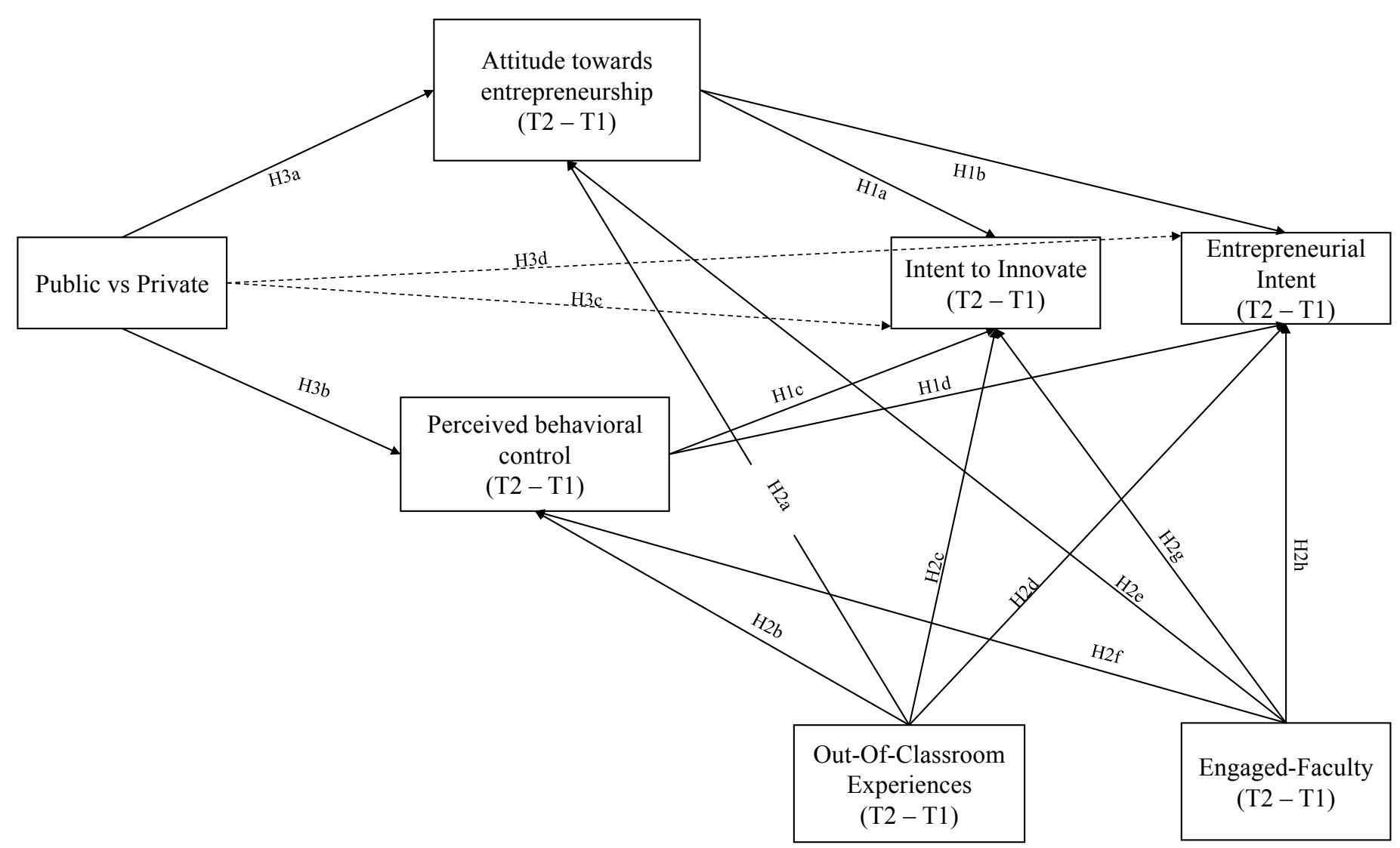

Figure 1: Theoretical Model with Hypothesized effect of out-of-class-experiences and engaging-faculty across private versus public universities 


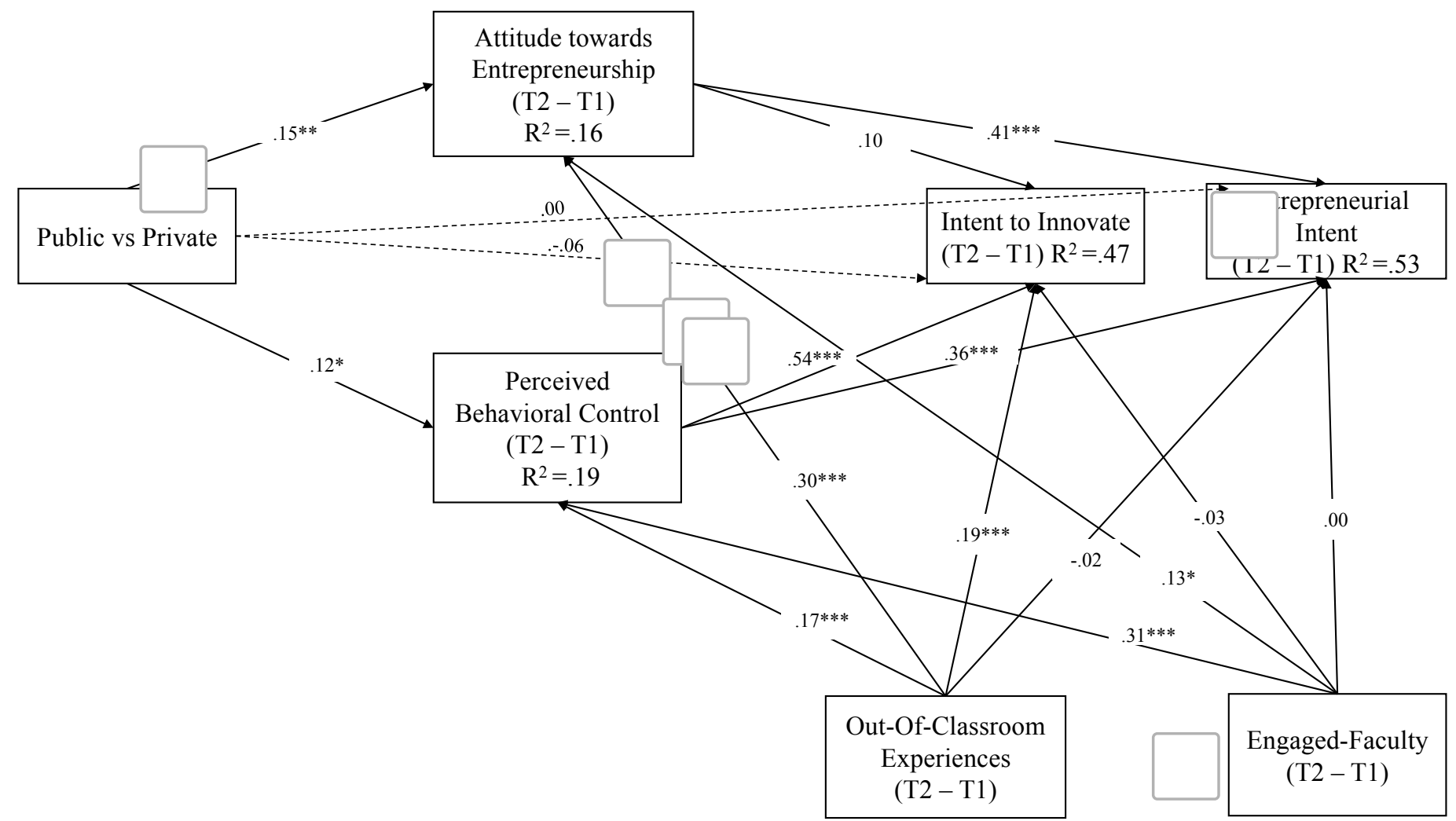

Model Fit: X $2(9)=13.44 ; \mathrm{RMSEA}=.04 ; \mathrm{SRMR}=.03 ; \mathrm{CFI}=1.00 ; * \mathrm{p}<.05 ; * * \mathrm{p}<.01 ; * * * \mathrm{p}<.001$. Control Variables: age, gender and entrepreneurial kin 


\begin{tabular}{|c|c|c|c|c|}
\hline & Hypotheses & $\begin{array}{l}\text { Standardized Path } \\
\text { Coefficients for } \\
\text { Structural Model } \boldsymbol{\beta}\end{array}$ & & $p$ \\
\hline H1a & The change in ATA is positively related to change in Int2Inv & .10 & $\mathrm{~ns}$ & Not Suported \\
\hline $\mathrm{H} 1 \mathrm{~b}$ & The change in ATA is positively related to a change in EI & .41 & $* * *$ & \\
\hline $\mathrm{H} 1 \mathrm{c}$ & The change in PBC is positively related to the change in Int2Inv & .54 & $* * *$ & \\
\hline H1d & The change in PBC is positively related to the change in EI & .36 & $* * *$ & \\
\hline $\mathrm{H} 2 \mathrm{a}$ & Out of Class experiences have positive effect on the change in ATA & .30 & $* * *$ & \\
\hline $\mathrm{H} 2 \mathrm{~b}$ & Out of Class experiences have positive effect on the change in PBC & .17 & $* * *$ & \\
\hline $\mathrm{H} 2 \mathrm{c}$ & Out of Class experiences have positive effect on the change in Int2Inv & .19 & $* * *$ & \\
\hline $\mathrm{H} 2 \mathrm{~d}$ & Out of Class experiences have positive effect on the change in EI & -.02 & ns & Not Supported \\
\hline $\mathrm{H} 2 \mathrm{e}$ & Engaged Faculty Influences have positive effect on the change in ATA & .13 & * & \\
\hline $\mathrm{H} 2 \mathrm{f}$ & Engaged Faculty Influences have positive effect on the change in PBC & .31 & $* * *$ & \\
\hline $\mathrm{H} 2 \mathrm{~g}$ & Engaged Faculty Influences have positive effect on the change in Int2Inv & -.03 & $\mathrm{~ns}$ & Not Supported \\
\hline $\mathrm{H} 2 \mathrm{~h}$ & Engaged Faculty Influences have positive effect on the change in EI & .00 & ns & Not Supported \\
\hline $\mathrm{H} 3 \mathrm{a}$ & $\begin{array}{l}\text { Students in Private Universities will have greater increase in ATA after compulsory } \\
\text { entrepreneurship education than students in Public universities. }\end{array}$ & .15 & $* *$ & \\
\hline $\mathrm{H} 3 \mathrm{~b}$ & $\begin{array}{l}\text { Students in Private Universities will have greater increase in PBC after compulsory } \\
\text { entrepreneurship education than students in Public universities. }\end{array}$ & .12 & * & \\
\hline $\mathrm{H} 3 \mathrm{c}$ & $\begin{array}{l}\text { Students in Private Universities will have greater increase in Int2Inv after } \\
\text { compulsory entrepreneurship education than students in Public universities. }\end{array}$ & -.06 & ns & Not Supported \\
\hline H3d & $\begin{array}{l}\text { Students in Private Universities will have greater increase EI after compulsory } \\
\text { entrepreneurship education than students in Public universities. }\end{array}$ & .00 & ns & Not Supported \\
\hline \multirow{3}{*}{ Controls } & Age & -.02 & $\mathrm{~ns}$ & \\
\hline & Gender & .09 & $* *$ & \\
\hline & Entrepreneurial Kin & .03 & ns & \\
\hline
\end{tabular}

R Squared: EI (Entrepreneurial Intention $)=.53 ; \operatorname{Int} 2 \operatorname{Inv}($ Intention to Innovate $)=.47 ;$ ATA (Attitude towards the act of entrepreneurship $)=.16 ;$ PBC (Perceived Behavioral Control) $=.19$

$*=p<.05 ; * *=p<.01 ; * * *=p<.001 ; \mathrm{ns}=$ Not Significant

Table 3: Summary of Hypotheses results 
PBC mediates the Public vs Private - Intention to Innovate relationship

PBC mediates the Public vs Private - Entrepreneurial Intention relationship

PBC mediates the engaged faculty - intention to innovate relationship

PBC mediates the engaged faculty - entrepreneurial intention relationship

$.14^{* *}$

PBC mediates the out-of-class experieces - entrepreneurial intention relationship

$23^{* *}$

PBC mediates the out-of-class experiences - intention to innovate relationship

$13 * *$

ATA mediates the Public vs Private - Intention to Innovate relationship

$.08^{* *}$

ATA mediates the Public vs Private - Entrepreneurial Intention relationship

$.03 \mathrm{~ns}$

ATA mediates the engaged faculty - intention to innovate relationship

ATA mediates the engaged faculty - entrepreneurial intention relationship

$23 * *$

ATA mediates the out-of-class experieces - entrepreneurial intention relationsh
ATA mediates the out-of-class experiences - intention to innovate relationship

$.01 \mathrm{~ns}$

$11^{*}$

$03 \mathrm{~ns}$

${ }^{*}=p<.05 ; * *=p<.01 ; * * *=p<0.00$

ATA $=$ Attitude Towards the Act of Entrepreneurship

$\mathrm{PBC}=$ Perceived Behavioral Control 
Table 5: Intercorrelations and Descriptive Statistics of Study Variables

\begin{tabular}{|c|c|c|c|c|c|c|c|c|c|c|c|c|c|c|c|c|c|c|}
\hline & Study Variable & $M$ & $S D$ & 1 & 2 & 3 & 4 & 5 & 6 & 7 & 8 & 9 & 10 & 11 & 12 & 13 & 14 & 15 \\
\hline 1 & Entrepreneurial Intention (T2) & 5.55 & 1.50 & .94 & & & & & & & & & & & & & & \\
\hline 2 & Intent to Innovate (T2) & 3.68 & 0.66 & $.65 * *$ & .84 & & & & & & & & & & & & & \\
\hline 3 & Attitude Towards the Act (T2) & 5.93 & 1.32 & $.66^{* *}$ & $.58 * *$ & .92 & & & & & & & & & & & & \\
\hline 4 & Perceived Behavioral Control (T2) & 4.52 & 1.00 & $.66^{* *}$ & $.67 * *$ & $.78^{* *}$ & .88 & & & & & & & & & & & \\
\hline 5 & Out-of-class-experience (T2) & 3.86 & 0.73 & $.15^{* *}$ & $.35 * *$ & $.32^{* *}$ & $.33^{* *}$ & .88 & & & & & & & & & & \\
\hline 6 & Engaged-faculty (T2) & 3.34 & 0.75 & $.19 * *$ & $.26 * *$ & $.28^{* *}$ & $.40^{* *}$ & $.43^{* *}$ & .88 & & & & & & & & & \\
\hline 7 & Entrepreneurial Intention (T1) & 5.87 & 1.26 & -.06 & -.04 & -.03 & -.03 & .00 & -.05 & .90 & & & & & & & & \\
\hline 8 & Intent to Innovate (T1) & 3.81 & 0.53 & .00 & .01 & .02 & .04 & .03 & .05 & $.56^{* *}$ & .74 & & & & & & & \\
\hline 9 & Attitude Towards the Act (T1) & 6.24 & 1.14 & -.04 & .02 & -.02 & .00 & .03 & .02 & $.69^{* *}$ & $.57 * *$ & .89 & & & & & & \\
\hline 10 & Perceived Behavioral Control (T1) & 4.71 & 0.90 & .00 & .02 & .07 & .06 & .10 & .02 & $.65^{* *}$ & $.65 * *$ & $.76^{* *}$ & .84 & & & & & \\
\hline 11 & Out-of-class-experience (T2) & 4.04 & 0.63 & -.05 & .04 & .00 & .05 & .03 & .07 & $.25 * *$ & $.45 * *$ & $.40^{* *}$ & $.35 * *$ & .84 & & & & \\
\hline 12 & Engaged-faculty (T1) & 3.47 & 0.69 & -.07 & -.04 & -.03 & -.06 & .02 & .03 & $.20^{* *}$ & $.27 * *$ & $.23 * *$ & $.30^{* *}$ & $.36^{* *}$ & .84 & & & \\
\hline 13 & Age & 3.75 & 2.02 & .06 & $.126^{*}$ & .08 & $.13^{*}$ & .10 & .05 & -.05 & .09 & .10 & $.15^{* *}$ & .08 & .04 & & & \\
\hline 14 & Gender & 0.52 & 0.50 & $.15^{* *}$ & .04 & .04 & .02 & -.06 & .09 & -.04 & -.02 & -.04 & -.03 & -.01 & .07 & $-.11 *$ & & \\
\hline 15 & Entrepreneurial Kin & 0.67 & 0.47 & .02 & .01 & .00 & .06 & -.05 & $.15 * *$ & -.04 & .04 & .02 & .00 & $.14 * *$ & .06 & -.07 & -.04 & \\
\hline 16 & University-type & 0.39 & 0.49 & .07 & -.05 & .06 & .02 & $-.13 *$ & .07 & $-.12 *$ & $-.12 *$ & $-.16^{* *}$ & $-.20 * *$ & -.06 & -.10 & $-.49 * *$ & .08 & $.22 * *$ \\
\hline
\end{tabular}

Diagonal values are Cronbach Alpha $(\propto)$

$\mathrm{T} 1=$ First measurement wave; $\mathrm{T} 2=$ Second measurement wave $\mathrm{N}=361 ; * * \mathrm{p}<.01 \cdot{ }^{*} \mathrm{p}<.05$

Age: $1=<18,2=18,3=19,4=20,5=21,6=22-25,7=26-30,8=>30$

Gender: $0=$ Male, $1=$ Female

Entrepreneurial Kin: $0=\mathrm{No}, 1=$ Yes
University-type: $0=$ Public, $1=$ Privat 


\section{Appendix -Scales for measurement}

\section{Entrepreneurial Intention - Liñán \& Chen 2009}

- Indicate your level of agreement with the following statements from 1 to 7

a. I am ready to do anything to be an entrepreneur

b. My professional goal is to become an entrepreneur

c. I will make every effort to start and run my own firm

d. I am determined to create a firm in the future

e. I have very seriously thought of starting a firm

f. I have the firm intention to start a firm some day

\section{Attitude - Liñán \& Chen 2009}

- Indicate your level of agreement with the following sentences from 1 (total disagreement) to 7 (total agreement).

a. Being an entrepreneur implies more advantages than disadvantages to me

b. A career as entrepreneur is attractive for me

c. If I had the opportunity and resources, I'd like to start a firm

d. Being an entrepreneur would entail great satisfactions for me

e. Among various options, I would rather be an entrepreneur Perceived

\section{Behavioral Control - Liñán \& Chen 2009}

- If you decided to create a firm, would people in your close environment approve of that decision? Indicate from 1 (total disapproval) to 7 (total approval).

a. To start a firm and keep it working would be easy for me

b. I am prepared to start a viable firm

c. I can control the creation process of a new firm

d. If I tried to start a firm, I would have a high probability of succeeding

\section{Intention to Innovate - Mayhew et. Al 2012}

- Please indicate how effective you are in each of the following areas: from extremely ineffective to extremely effective

a. Identifying new opportunities (such as a new product or service a more effective way of accomplishing tasks, or a new way to solve a common social problem)

b. Developing a strategy to direct your and others' efforts in the direction of realizing new opportunities (such as developing an action plan).

c. Acquiring resources necessary to realize a new opportunity (such as area/topic expertise).

d. Creating an entity to take advantage of a new opportunity (for example, an organization devoted to the new opportunity). 


\section{Engaged-Faculty - Mayhew et. Al 2012}

- Indicate your level of agreement/disagreement with each of the followings statements: from strongly disagree to strongly agree

a. Faculty challenge me to think outside of the box to create solutions to problems presented in class

b. Faculty ask me to show how a particular course concept could be applied to an actual problem or situation

c. Faculty ask me to point out any fallacies in basic ideas, principles, or points of view represented in the course

d. Faculty ask me to argue for or against a particular point of view

e. Faculty encourage me to explore original ideas

\section{Co-Curricular activities - Mayhew et. Al 2012}

- Indicate your level of agreement/disagreement with each of the followings statements: from strongly disagree to strongly agree

Think of your out-of-class experience in a broad sense that includes any activity you engaged in whilst studying at the university.

a. My out-of-class experiences had a positive influence on my intellectual growth and ideas

b. My out-of-class experiences helped me to connect what I learned in the classroom with life events

c. My out-of-class experiences helped me translate knowledge and understanding from the classroom into action

d. My out-of-class experiences had a positive influence on my personal growth, attitude, and values 